\title{
Mycotic "Pseudotumors" of the Breast
}

\author{
Report of Four Cases
}

Karlhanns Salfelder, MD, Jan Schwarz, MD

Four patients are reported with mycotic pseudotumors of the breast. Two of the granulomas were due to involvement by histoplasmosis, one by blastomycosis, and one by cryptococcosis. In the three patients who were treated surgically, tumor was suspected preoperatively in two and an infected cyst in one. The fourth granuloma, that due to cryptococcosis, was unsuspected clinically and discovered at autopsy. Surgical excision was effective therapy in those so treated. A critical review of the literature revealed only one other previously published case (cryptococcic mastitis) of deep mycosis of the breast.

$\mathrm{T}$ he breast has rarely been reported as a site of fungal infection and, of the cases on record, only one is acceptable as deep mycosis.' However, since from one single laboratory four cases of mycotic mastitis were reported in a nine-year-period, the true incidence must be higher than recorded, and this differential diagnosis must be concidered in breast "tumors" that presently are looked for and detected more actively with the help of roentgenographic methods.

\section{REPORT OF CASES}

CASE 1.-A cryptococcosis was found in both breasts of a young woman with a ten-month history of disseminated lupus erythematosus with nephritis and renal failure. She was treated with cortisone and dialyzed on several occasions. On autopsy, disseminated cryptococcosis was found in lungs, brain, meninges, liver, spleen, ovaries, and breast. Numerous cryptococci were seen in the breast tissue (Fig 1). A mild meningitis was observed across the cerebellum. As is frequently the case in cryptococcosis, no inflammatory response was seen in the other tissue (Table).

CASE 2.-A unilateral blastomycosis of the breast clinically ap pearing as an abscess was diagnosed preoperatively as (infected?) para-areolar cyst. After excision, drainage, and topical antifungal treatment, complete healing took place. Fungus cells with single

Accepted for publication Oct 17, 1974

From the Department of Pathology, College of Medicine, University of Cincinnati (Drs. Salfelder and Schwarz), and the Clinical Laboratories, Jewish Hospital (Dr. Schwarz), Cincinnati. Dr. Salfelder is currently with the Department of Pathology, University of Mérida, Venezuela.

Reprint requests to Clinical Laboratories, Jewish Hospital, Cincinnati, OH 45229 (Dr. Schwarz). buds morphologically consistent with Blastomyces dermatitidis were seen, as well as a characteristic tissue reaction (Fig 2). After eight years, the patient is well and there are no signs of disease in the breast or elsewhere in the body (Table).

CASE 3.-A unilateral mastitis was found in a young woman with a large caseous nodule in the breast. Preoperatively, the diagnosis was breast tumor. Yeast cells of Histoplasma capsúlatum were seen in the histologic sections (Fig 3); the titer in the complement fixation test was 1:32. The patient is well and the breast normal 1' years after the resection (Table).

CASE 4.-The findings were clinically interpreted as breast tumor. The mass in the lateral mammary region was excised and found to be lymph nodes of the anterior axillary area, with granulomas. In the numerous, partly necrotic epithelioid cell granulomas, only single fungus cells could be seen (Fig 4); on culture, $\mathrm{H}$ capsulatum grew and the results of serologic study were abnormal. The patient is alive and apparently well (telephone report); a clinical re-examination could not be performed (Table).

\section{COMMENT}

Cryptococcic mastitis has been described only once before, also at autopsy. The diagnosis was made on re-examination of an old museum specimen.' The fungus cells in our patient, situated in the stroma of the breast without any inflammatory reaction, could easily be overlooked. Lack of inflammatory response is known as one form of "reaction" in cryptococcosis. The bilateral character of breast involvement points to a hematogenous pathway.

The two reports on blastomycotic mastitis in the literature require only brief comments; neither case justifies its inclusion as blastomycotis." Jung,' after discussing a case of disseminated "blastomycosis," described a "sporotrichoma" of the breast. The first case has no breast involvement; the second is not blastomycotic.

Kühlmeier \& Kreitner4 identified from a granulomatous breast lesion a yeast (Torulopsis inconspicua). This organism is not an accepted obligatory pathogen and has no relation to blastomycosis (in America identified by the etiologic agent $B$ dermatitidis).

Beside these two reports, no mention of involvement of the breast in blastomycosis was found in the literature.' In our patient with blastomycosis, we assume that a pri- 


\begin{tabular}{|c|c|c|c|c|}
\hline \multicolumn{5}{|c|}{ Clinical and Pathologic Findings in Four Patients With Deep Mycoses of the Breast } \\
\hline $\begin{array}{l}\text { Patient } \\
\text { No./Age, } \\
\text { yr }\end{array}$ & $\begin{array}{l}\text { Duration, } \\
\text { Clinical Findings, } \\
\text { "Preoperative } \\
\text { Diagnosis" }\end{array}$ & Gross Appearance $\underline{\&}$ Histologic Findings & Other Findings & Therapy \& Follow-Up \\
\hline $1 / 2010$ & mo & $\begin{array}{l}\text { Not recognizable grossly; microscopically: } \\
\text { pale yeast cells of different sizes with } \\
\text { capsule; positive stain with mucicarmine; }\end{array}$ & $\begin{array}{l}\text { Disseminated lupus } \\
\text { erythematosus with } \\
\text { generalized cryptococcosis }\end{array}$ & Steroids; death \\
\hline $2 / 30$ & $\begin{array}{l}2 \text { mo; para-areolar } \\
\text { swelling fluctua- } \\
\text { tion \& deep } \\
\text { induration; } \\
\text { "infected cyst" }\end{array}$ & $\begin{array}{l}\text { Suppurated mass of } 4 \mathrm{~cm} \text { diameter; purulent } \& \\
\text { granulomatous inflammation with destruction } \\
\text { of breast tissue; epithelioid cell granu- } \\
\text { lomas \& multinucleated gaint cells; yeast } \\
\text { cells } 10 \mu \text { to } 15 \mu \text { with occasional single, } \\
\text { broad-based buds, intensely stained with } \\
\text { Grocott \& Gridley procedures; consistent } \\
\text { with B dermatitidis }\end{array}$ & $\begin{array}{l}\text { Clinically well; } \\
\text { normal chest } \\
\text { roentgenograms }\end{array}$ & $\begin{array}{l}\text { Surgical excision; } \\
\text { amphotericin B } \\
\text { ointment; well after } \\
8 \mathrm{yr}\end{array}$ \\
\hline $3 / 21$ & $\begin{array}{l}\text { Slow-growing } \\
\text { mass; "breast } \\
\text { tumor" }\end{array}$ & $\begin{array}{l}\text { Firm nodule } 3 \mathrm{~cm} \text { in diameter, para-areolar; } \\
\text { partly caseated granulomatous mass replacing } \\
\text { breast tissue; epithelioid cell granulomas, } \\
\text { multinucleated giant cells, lymphocytes; G } \\
\text { rocott- positive ovoid yeast cells } 2 \mu \text { to } 4 \mu \text {; } \\
\text { occasional buds }\end{array}$ & $\begin{array}{l}\text { Complement fixation } \\
\text { test (CFT) } \\
\text { (histoplasmosis) } \\
1: 32 ; \text { no evidence of } \\
\text { systemic or } \\
\text { pulmonary }\end{array}$ & $\begin{array}{c}\text { Surgical excision; } \\
\text { well } 2 \text { yr later }\end{array}$ \\
\hline $4 / 55 \mathrm{Ma}$ & $\begin{array}{l}\text { ass noted } 6 \text { mo } \\
\text { ago, slowly increasing; } \\
\text { "breast tumor? } \\
\text { axillary } \\
\text { lymphadenopathy?" }\end{array}$ & $\begin{array}{l}\text { Nodular mass with individual "tumors" up to } \\
5 \mathrm{~cm} \text { from anterior axillary line, clinically } \& \text { on } \\
\text { xerogram considered breast mass; excision of } \\
\text { axillary fat } 13: 13: 5 \mathrm{~cm} \text { with large brown lymph } \\
\text { nodes; massive epithelioid cell granulomas in } \\
\text { huge lymph nodes with discrete necrosis; rare } \\
\text { organisms on Grocott stain, } 2 \mathrm{u} \text {, to } 4 \mathrm{u} \text {, }\end{array}$ & $\begin{array}{l}\text { Culture positive for } \\
\text { H capsulatum; } \\
\text { CFT (histoplasmosis) } \\
1: 4 ; \text { no evidence } \\
\text { systemic } \\
\text { histoplasmosis }\end{array}$ & $\begin{array}{l}\text { Surgical excision; } \\
\text { alive } 1 \text { yr later; } \\
\text { uncooperative, re } \\
\text { fuses check-up of }\end{array}$ \\
\hline
\end{tabular}
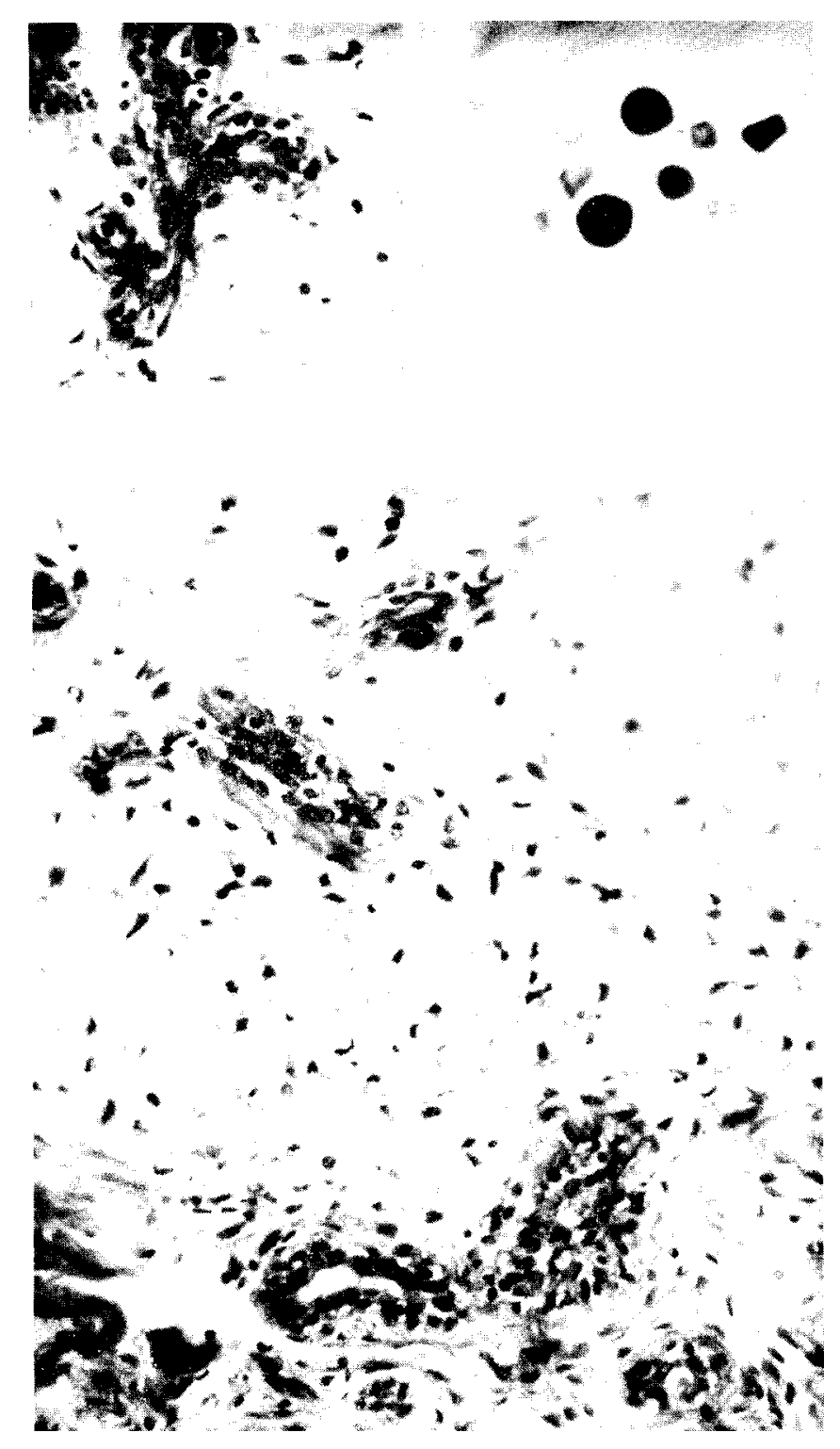

Fig 1.-Accumulation (case 1) of pale staining cryptococci with halo, replacing breast tissue; no inflammatory reaction (hematoxylineosin, $\times 300)$. Inset, Cryptococci of different sizes. One with single bud; others distorted (Grocott stain, x 500).

mary lung lesion became arrested. Prior to the healing of the lung lesion, a hematogenous spread must have occurred with a solitary metastasis to the breast. Single "metastatic" lesions in the skin or bone without clinical or roentgenographic evidence of activity in the lungs are well known in blastomycosis. ${ }^{5}$ To postulate a traumatic inoculation into the breast seems farfetched, despite the exceptional observation of this mechanism in blastomycotic skin lesions (laboratory accidents).

Histoplasmic mastitis has not been reported previously. The occurrence of this organ manifestation in a highly endemic region of histoplasmosis does not surprise, since a subclinical hematogenous dissemination into other organs after a benign primary lung infection is well documented.' Lesions from this fungemia in benign primary infections almost always become arrested and heal, leaving residual nodules, often calcified. As shown in our case 4, axillary histoplasmic lymphadenitis may appear clinically as a breast lesion and be mistakenly diagnosed and operated as a breast tumor.

\section{PATHOGENESIS}

Cryptococcosis is seen mostly in immunosuppressed patients, particularly in cases of lymphoma and in transplants. Meningitis is the most common and most severe complication.

Histoplasmosis is a common disease in the endemic area comprising much of the Ohio-Mississippi valley. Acquired

Mycotic "Pseudotumors" of the Breast/Salfelder \& Schwarz 
by inhalation of spore-containing dust, the disease commonly disseminates during primary infections. The most frequent type of dissemination is self-limited and benign; in infants, however, the dissemination can be disastrous. Histoplasmic metastatic lesions (the primary focus is almost, without exception, in the lung) have been found in practically every organ; spleen and liver are the most common, and adrenal and brain the most consequential sites.'

Blastomycosis shares the pathogenesis with histoplasmosis; soil-borne spore-containing dust is inhaled and a pulmonary primary complex is formed. The skin is by far the most common site of peripheral dissemination, with prostate, joints, and meninges competing as sites of importance.'

Fig 2.-Granulation tissue (case 2) with multinucleated giant cells replacing breast tissue (hematoxylin-eosin, x300). Inset, Budding yeast cell of B dermatitidis. Note broad-based daughter cell (Grocott stain, $x$ 1,000).
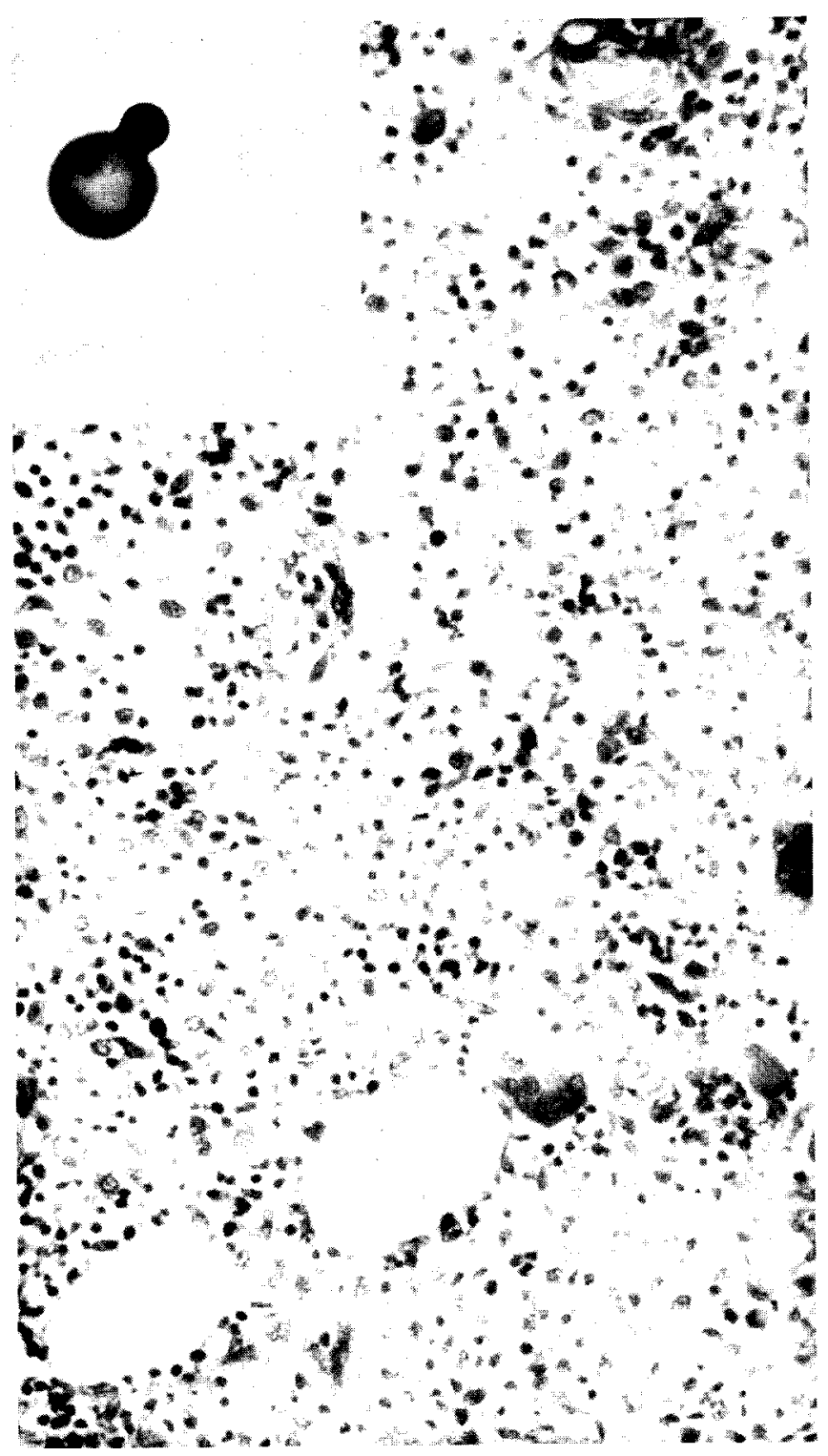

The influence of steroid therapy, in the activation of histoplasmosis and blastomycosis is undeniable but, compared with cryptococcosis, much less prominent.

There is no evidence that any of the three diseases is transmitted from man to man, or directly from animal to man. Pigeons (in cryptococcosis) and blackbirds and bats (in histoplasmosis) play a part in connection with the presence of Cryptococcus neoformans and $H$ capsulatum, respectively, in soil, but the exact role of these winged animals is not established. The mechanism of how $\mathrm{B}$ dermatitidis reaches the soil is unknown.

It is difficult to determine why mycotic mastitis has not been described more often. This may be due to lack of suspicion or to failure to recognize the causative agents in

Fig 3.-Granulomatous reaction (case 3 ) in periphery of caseous focus of breast, with abundant epithelioid cells and multinucleated giant cells (hematoxylin-eosin, x250). Inset, Three cells of $\mathrm{H}$ capsulatum from necrotic area (Grocott stain, $x 1,300$ ).

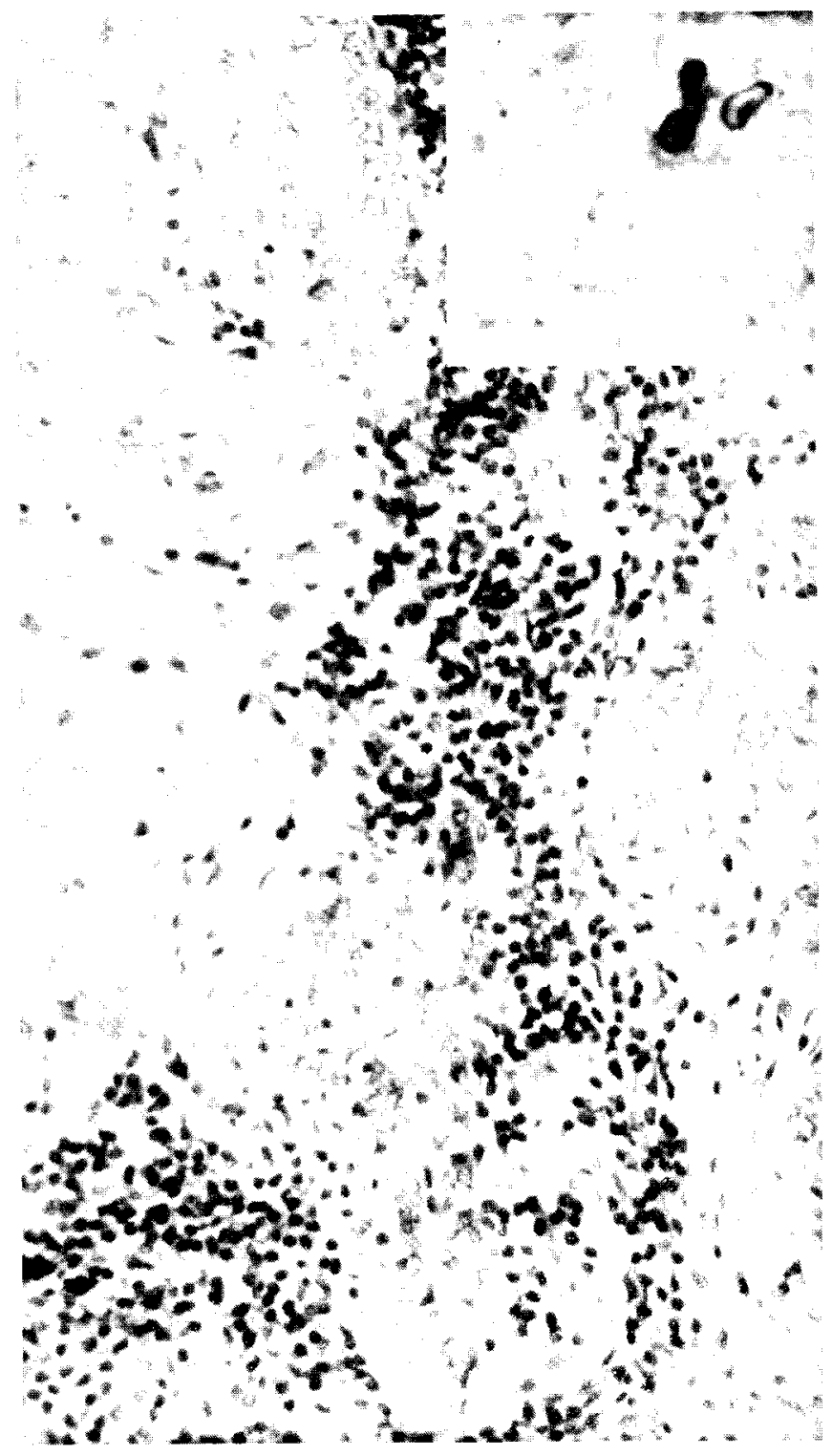




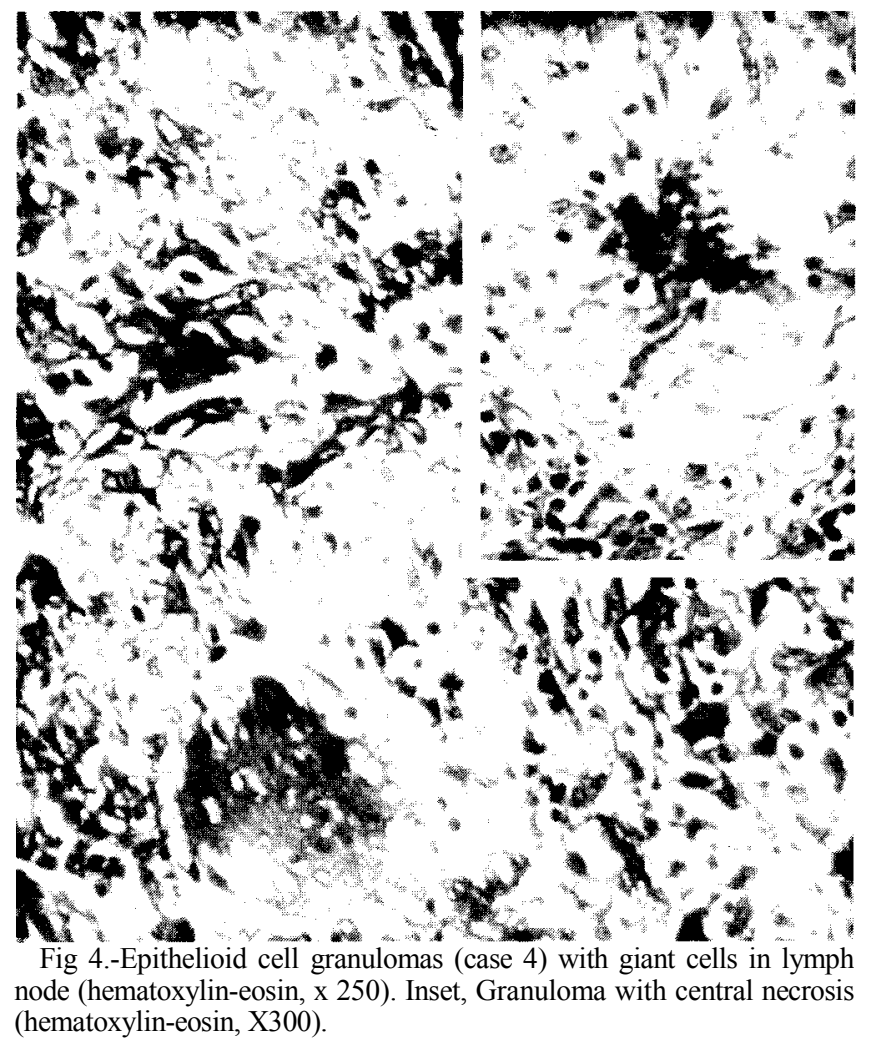

tissue sections or on culture. The use of special stains, especially the Grocott-methenamine silver stain, is indispensable for detection of fungi in tissue.' As cases of granulomatous mastitis (simulating carcinoma) are found clinically more often,9,' ${ }^{\circ}$ mycotic mastitis should become more frequently recognized.

\section{References}

1. Symmers WStC: Deep-seated fungal infections currently seen in the histopathologic service of a medical school laboratory in Britain. Am J Clin Pathol 46:515-537, 1966.

2. Salfelder K: Cryptococcosis, in Handbuch der Speziellen Pathologischen Anatomie and Histologie, New York, Springer Publishing Co, 1971, vol 3, pp 383-464.

3. Jung Disseminierte Gilchristsche Blastomykose and Sporotrichom der Mamma mit Bild and Kulturdemonstration. Arch Dermatol Syph 191:482-484, 1950.

4. KShlmeier W, Krietner H: Blastomykose der Mamma. Wien Klin Wochenschr 65:13-15, 1953.

5. Vanék J, Schwarz J, Hakim S: North American blastomycosis. Am J Clin Pathol 54:384-400, 1970.

6. Landay ME, Schwarz J: Primary cutaneous 'blastomycosis. Arch Dermatol 104:408-411,1971.

7. Vanék J, Schwarz J: The gamut of histoplasmosis. Am J Med 50:89-104, 1971.

8. Grocott RG: A stain for fungi in tissue sections and smears using Gomari's methenamine-silver nitrate technique. Am J Clin Pathol 25:975-979, 1955.

9. Kessler E: Granulomatous mastitis: A lesion clinically simulating carcinoma. Am J Clin Pathol 58:642-646, 1972

10. Murthy MSN: Granulomatous mastitis and lipogranuloma of the breast. Am J Clin Pathol 60:432-433, 1973 